\title{
Increasing ATP conservation in maltose consuming yeast, a challenge for industrial organic acid production in non-aerated reactors
}

\author{
Stefan de Kok ${ }^{1}$, Wesley Leoricy Marques ${ }^{2 *}$, Robert Mans ${ }^{1}$, Duygu Yilmaz ${ }^{1}$, Erwin Suir ${ }^{1}$, Jack T Pronk ${ }^{1}$, \\ Andreas K Gombert ${ }^{2,3}$, Jean-Marc Daran ${ }^{1}$, Antonius JA van Maris ${ }^{1}$ \\ From 5th Congress of the Brazilian Biotechnology Society (SBBIOTEC) \\ Florianópolis, Brazil. 10-14 November 2013
}

Anaerobic fermentation processes are economically attractive for industry, as costs for aeration and stirring are greatly reduced. An example of such a process is (bio) ethanol production by Saccharomyces cerevisiae, in which a low but positive ATP gain leads to elevated product yields. However, for other fermentative pathways, such as in an engineered homolactic strain of $S$. cerevisiae, the net ATP gain for the fermentation of glucose to lactate is null due to the requirement of ATP for product export. Therefore, increasing the conservation of ATP is of major importance for such 'zero-ATP pathways'.

One opportunity to increase ATP conservation arises when disaccharides are used as a substrate. In many industrial microorganisms, disaccharides are cleaved by hydrolysis, which results in the dissipation of energy that is available in this cleaving reaction. However, phosphorolytic cleavage could be used to replace the hydrolysis of disaccharides, thereby increasing the ATP yield.

In this study, growth of S. cerevisiae on maltose was used as a model. All known native maltose metabolism genes were removed and replaced by a maltose phosphorylase (Lactobacillus sanfranciscensis) and a single overexpressed copy of the native MAL11 maltose transporter. Because maltose phosphorylase cleaves maltose into glucose and $\beta$ glucose-1-phosphate, additionally a $\beta$-phosphoglucomutase (Lactococcus lactis) was co-expressed in this strain.

Anaerobic maltose-limited chemostat cultures showed that replacement of maltose hydrolysis by phosphorolysis increased the biomass yield of the mutant strain by $26 \%$ over the wild type strain, demonstrating the potential of

${ }^{2}$ Department of Chemical Engineering, University of São Paulo, São Paulo, Brazil

Full list of author information is available at the end of the article phosphorolysis to improve ATP conservation of disaccharide metabolism in industrial microorganisms [1].

\section{Authors' details}

${ }^{1}$ Department of Biotechnology, Delft University of Technology and Kluyver Centre for Genomics of Industrial Fermentation, Julianalaan 67, 2628 BC Delft, The Netherlands. ${ }^{2}$ Department of Chemical Engineering, University of São Paulo, São Paulo, Brazil. ${ }^{3}$ Faculty of Food Engineering, University of Campinas, São Paulo, São Paulo, Brazil.

Published: 1 October 2014

\section{Reference}

1. De Kok S, Yilmaz D, Suir E, Pronk JT, Daran JM, van Maris AJA: Metab Eng 2011, 5:518-526.

doi:10.1186/1753-6561-8-S4-P185

Cite this article as: de Kok et al.: Increasing ATP conservation in maltose consuming yeast, a challenge for industrial organic acid production in non-aerated reactors. BMC Proceedings 2014 8(Suppl 4):P185.
Submit your next manuscript to BioMed Central and take full advantage of:

- Convenient online submission

- Thorough peer review

- No space constraints or color figure charges

- Immediate publication on acceptance

- Inclusion in PubMed, CAS, Scopus and Google Scholar

- Research which is freely available for redistribution

Submit your manuscript at www.biomedcentral.com/submit
() Biomed Central 